\title{
Correlation, Path Analysis and RAPD Markers in Sorghum (Sorghum bicolor L. Moench) Genotypes
}

\author{
Khaled, A. G. A. ${ }^{1}$; Aml A. Tag El-Din ${ }^{2}$ and Eatemad M. hussein ${ }^{2}$ \\ ${ }^{1}$ Department of Genetics, Faculty of Agriculture, Sohag University, Sohag 82786 Egypt. \\ ${ }^{2}$ Department of Sorghum, Field Crops Researh Institute, Agriculture Researh Center.
}

\section{Abstract:}

Genetic diversity is one of the key factors for the improvement of many crop plants including sorghum. Fifteen sorghum genotypes were planted in 2012 and 2013 seasons to compare among them for agronomic traits and molecular level. The combined analysis for agronomic traits and yield components showed significant differences among genotypes for all studied traits. The highest mean values of 1000 -kernel weight $(36.08 \mathrm{~g})$ and number of seeds/panicle traits (1315.9) were obtained from Giza-15 genotype. The lowest mean values of 1000kernel weight (17.07g) and number of seeds/panicle traits (646.9) were obtained from local-162 and El-Kharga genotypes, respectively. Values of correlation analysis indicated that 1000-kernel weight was positive and highly significant correlation with grain weight (0.749). The path analysis showed that 1000-kernel weight had high and positive direct effect on grain weight $(0.7102)$, also number of seeds/panicle had positive direct effect on grain weight (0.1443) but it had negative direct effect through plant height (-0.1876). Genetic diversity of sorghum genotypes detected using of Random Amplified Polymorphism DNA (RAPD) markers. 76 DNA bands were obtained from 12 primers which could detected a percentage of polymorphism ranged from 40 to $100 \%$ with an average of $73.36 \%$. The average of polymorphic bands was 4.67 per primer. The dendrogram based on RAPD marker gave three main groups; the first group contains three genotypes, but the second group sub-divided into two sub-clusters, which contain three genotypes each. The third group contains six genotypes. The similarity percent based on agronomical traits was not significantly correlated $(\mathrm{r}=$ 0.07961) with the genetic distance based on RAPD markers.

Keywords: correlation; sorghum genotypes; path analysis; RAPD markers; variance analysis.

Received on: 22/9/2014

Accepted for publication on: 29/9/2014

Referees: Prof. Adel S. Teghian

Prof. Adel M. Mahmoud 


\section{Introduction:}

Sorghum (Sorghum bicolor L. Moench) is fifth in worldwide economic importance among the cereal crops. It is an important food, feed, forage and provides raw material for producing of starch, fiber, dextrose syrup, biofuel and other products. The sorghum is a staple food crop of millions of the poor in semi-arid tropics of Africa and Asia (Zidenga 2004). In Egypt it is fourth most important cereal after wheat, rice and maize. Many scientists have been mostly worked to assess patterns of sorghum genetic variation based on morphological characters (Appa-Rao et al. 1996 and Djè et al. 1998) or pedigree (Jordan et al. 1998). However, morphological variation does not reliably reflect the real genetic variation because of genotype environment interactions and the largely unknown genetic control of poly-genetically inherited morphological and agronomical traits (Smith and Smith, 1992).

Molecular markers successfully developed during the last decades have largely overcome the problems that are associated with phenotypebased markers. One of such techniques is the use of RAPD (Williams et al. 1990). The advantages of RAPD is its simplicity, rapidity, requirement for only a small quantity of DNA, and the ability to generate numerous polymorphisms (Cheng et al. 1997) with good coverage of the entire genome (Melchinger,1993). The information obtained through germplasm characterization using RAPD is extensively used for the identification of germplasm, screening of duplicates, assessing genetic diversity and monitoring the genetic stability of conserved germplasm.

RAPD markers have been used in important crops as Barley (Hoffman et al. 2003), Cotton (Dongre and Parkhi, 2005), Sorghum (Jeya et al. 2006), Faba bean (Tanttawi et al. 2007), Cowpea (Abdelsabour et al. 2010) and wheat (khaled et al. 2013). Ayana et al. (2000) assessed the extent of genetic variation among 80 sorghum accessions from Ethopia and Eritrea using 20 RAPD primers and found limited variation among the accessions.

Yield is the final performance of any crop and conditioned by a complicated genetic system. Yield potential accompanied with desirable combination of traits has always been the major objective of sorghum breeding program. Correlation measure the level of dependence on traits and out of numerous correlation coefficients, it is often difficult to determine the actual mutual effects among traits. The estimates of correlation alone may be often misleading due to mutual cancellation of component traits. So, it becomes necessary to study path coefficient analysis, which takes in to account the casual relationship in addition to degree of relationship. The path coefficient analysis initially suggested by Wright (1960) and described by Dewey and Lu (1959) allows partitioning of correlation coefficient into direct and indirect contributions (effects) of various traits towards dependent variable and thus helps in assessing the cause-effect relationship as well as effective selection. Ikanovic et al. (2011) concluded that even if correlation values are similar for certain pairs of traits, direct effects for some of them and especially indirect effects via other traits can differ for some traits. Mostafa et al. (1992) reported that there was no significant relationship between days to $50 \%$ flowering and grain weight while 
plant height was significantly positively correlated with yielded and 1000-kernel weight. Mahajan et al. (2011), Wankhede et al. (1985), Mallinath et al. (2004) and Ambekar et al. (2000) stated that panicle length, panicle width, plant height and grain weight / panicle had showed positive significant association at both levels with all characters except days to $50 \%$ flowering.

Understanding genotypes diversity is of interest in the study of evolutionary forces under domestication, and has applications in the design of programs for the conservation, management and use in breeding programs of genetic resources. Therefore, the aims of this present study were to 1) determine the traits having greater interrelationship with grain weight utilized the correlation and path analysis, 2) determine the pattern of variations among 15 Sorghum genotypes from different agro-ecological regions in Egypt using RAPD markers, and agronomical characterization and 3) determine the degree of genetic relationships among these accessions.

\section{Materials and Methods: Field experiments:}

This experiment was conducted at Arab El-Awamer Research Station, Assiut, Egypt during two successive seasons, 2012 and 2013 seasons to study the correlation and genetic diversity in 15 sorghum genotypes. The genotypes were grown in a randomized complete block design (RCBD) with three replications under stressed soil and irrigation by spray. Each genotype was planted in one row plot, 4 meter long, and $0.6 \mathrm{~m}$ wide and hill to hill distance of $0.20 \mathrm{~m}$ apart with two plants / hill after thinning. All other cultural practices were carried out as recommended for sorghum production in both seasons. The studied traits were: plant height $(\mathrm{cm})$, days to $50 \%$ flowering, panicle length $(\mathrm{cm})$, panicle width $(\mathrm{cm}), 1000$-kernel weight $(\mathrm{g})$, number of seeds/panicle and grain weight ( $\mathrm{g}$ ).

\section{Statistical Analysis:}

Data for all traits were subjects to analysis of variance according to Steel and Torrie (1980) to evaluate the significant differences among the genotypes. Estimation of variation components and phenotypic correlations were calculated as suggested by Burton (1952), Wright (1960) and Narasimharao and Rachie (1964). The correlation coefficient was partitioned into direct and indirect causes according to Dewey and $\mathrm{Lu}$ (1959) and Turner and Stevens (1959). Test of significance was carried out with (n-2) degree of freedom for phenotypic correlation by referring to table given by Snedecor and Cochran (1989).

\section{DNA extraction and PCR proce- dures:}

Fresh young leaves were harvested and immediately ground in extraction buffer using cetyltrimethylammonium bromide (CTAB) protocol as described by Poresbski et al. (1997). A total of thirty varied 10-mer random primers (Metabion International AG, Germany) were scanned across the fifteen genotypes. Amplification was carried out in a DNA Thermal Cycler (Primus 25, Germany) according to the methods described by Williams et al. (1990). Genomic DNA was diluted 10-fold in water prior to cycles of PCR amplification with Go Taq ${ }^{\circledR}$ Green Master Mix (Promega, Madison, USA). PCR amplification was programmed for conditions with preliminary initial denaturation cycle at $95^{\circ} \mathrm{C}$ for five minutes. The following 35 cycles 
were composed of: denaturation step at $95^{\circ} \mathrm{C}$ for $1 \mathrm{~min}$, annealing step for 1 $\min$ at $38^{\circ} \mathrm{C}$ and elongation step at $72^{\circ} \mathrm{C}$ for $1 \mathrm{~min} 30 \mathrm{~s}$. The amplified fragments were visualized and photographed using UVP Bio Doc-It imaging system (USA).

\section{RAPD analysis:}

The DNA banding patterns generated from RAPD analysis were analyzed by a computer program, Gene Profiler (version 4.03). Microsoft excel file was prepared for scoring the data as ' 1 ' for matched and ' 0 ' for the unmatched of DNA band of every genotype. In order to detect patterns of genetic relationship among sorghum genotypes based on RAPD analysis and means of all studied traits, the similarities were computed based on percent of similarity method by UPGMA (Unweighted Pair Group Method with Arithmetic Average) method using MVSP (version 3.1) program. The average of similarity matrix was used to generate a tree for cluster analysis. A cophenetic matrix was derived from each matrix to test goodness of fit of the clusters by comparing the two matrices using the Mantel test (Mantel 1967). Finally, the correlation between each distance pair using computer program NTSYSpc version 2.2 was calculated (Rolhf 2000).

\section{Results and Discussion:}

The analysis of variance for yield and its attributes traits (Table 1) revealed that the differences among genotypes were highly significant $(p \leq 0.01)$ for all the studied traits. The data regarding means of grain weight and other characters of genotypes over two years are represented in Table (2) that focused the significant $(\mathrm{p} \leq 00.05)$ variation among sorghum genotypes in all studied traits. The highest range of individual trait was registered with regard to plant height (108 - 261.8 $\mathrm{cm}$ ), number of days to $50 \%$ flowering (70.17 - 97 day), panicle length $(14.17-21.12 \mathrm{~cm})$, panicle width $(6.65-9.41 \mathrm{~cm}), 1000$-kernel weight $(17.17$ - $36.08 \mathrm{gm})$, number of seeds/panicle (646.9 - 1315.9 seed) and grain weight / plant from (17.07 $37.25 \mathrm{~g}$ ). These variations among genotypes in all studied traits may be due to the genetic behavior combination with environmental factors, which were suitable for one genotype more than other. These finding are in agreement with these obtained by House (1985) and Mahdy et al. (2011). Furthermore, data in table 1 showed highly interaction between years and genotypes in studied traits expect number of seeds/panicle.

Table 1: Mean squares for combined analysis of variance for all studied traits.

\begin{tabular}{|c|c|c|c|c|c|c|c|c|}
\hline S.O.V. & d.f & $\begin{array}{c}\text { Plant } \\
\text { height } \\
\text { (cm) }\end{array}$ & $\begin{array}{c}\text { Days to } \\
\text { 50\% flo- } \\
\text { wering }\end{array}$ & $\begin{array}{c}\text { Panicle } \\
\text { length }\end{array}$ & $\begin{array}{c}\text { Panicle } \\
\text { width }\end{array}$ & $\begin{array}{c}\text { 1000- } \\
\text { kernel } \\
\text { weight }\end{array}$ & $\begin{array}{c}\text { No. of } \\
\text { seeds/ Pa- } \\
\text { nicle }\end{array}$ & $\begin{array}{c}\text { Grain } \\
\text { weight }\end{array}$ \\
\hline Year & 1 & 13.46 & $711.2 * *$ & 4.534 & $1.792 * *$ & $65.03 *$ & $46564.2 * *$ & 75.44 \\
\hline Error (a) & 4 & 53.20 & 7.911 & 7.602 & 0.059 & 5.093 & 1911.5 & 10.50 \\
\hline Genotypes & 14 & $16931.8 * *$ & $404.3 * *$ & $26.96^{* *}$ & $6.202 * *$ & $154.7 * *$ & $234239.8 * *$ & $257.14 * *$ \\
\hline $\begin{array}{c}\text { Year } x \\
\text { genotypes }\end{array}$ & 14 & $516.53 * *$ & $100.28^{* *}$ & $6.424 * *$ & $1.113 * *$ & $3.629 * *$ & 6351.3 & $15.233 * *$ \\
\hline Error (b) & 56 & 48.71 & 4.268 & 0.984 & 0.123 & 1.430 & 5951.3 & 3.793 \\
\hline
\end{tabular}

$*, * *$ significant at $5 \%$ and $1 \%$ level of probabilities, respectively. 
Phenotypic correlation are presented in Table 3 showed significant $(p \leq 0.05)$ and positive association of panicle width with plant height (0.563), whereas it is negative and non-significant association with days to $50 \%$ flowering $(-0.385)$. The correlation of kernel weight trait is positive and highly significant $(\mathrm{p} \leq 0.01)$ with grain weight (0.749), but it is negative and non-significant with plant height (-0.067).

Table 2: The mean performances of the 15 sorghum genotypes for yield and its components over two years.

\begin{tabular}{|l|c|c|c|c|c|c|c|}
\hline Genotypes & $\begin{array}{c}\text { Plant } \\
\text { height } \\
\text { (cm) }\end{array}$ & $\begin{array}{c}\text { Days to } \\
\mathbf{5 0 \%} \\
\text { flowering }\end{array}$ & $\begin{array}{c}\text { Panicle } \\
\text { length }\end{array}$ & $\begin{array}{c}\text { Panicle } \\
\text { width }\end{array}$ & $\begin{array}{c}\text { 1000- } \\
\text { kernel } \\
\text { weight (g) }\end{array}$ & $\begin{array}{c}\text { No. of } \\
\text { seeds/ } \\
\text { Panicle }\end{array}$ & $\begin{array}{c}\text { Grain } \\
\text { weight } \\
\text { (g) }\end{array}$ \\
\hline Giza-54 & 208.4 & 73.17 & 15.22 & 9.417 & 29.85 & 957.4 & 25.90 \\
\hline Giza-114 & 258.8 & 81.17 & 18.55 & 8.050 & 28.28 & 743.5 & 22.98 \\
\hline $10-1285$ & 196.3 & 73.17 & 15.60 & 9.350 & 30.52 & 1274.9 & 35.83 \\
\hline Giza-113 & 261.8 & 80.50 & 16.27 & 8.200 & 31.12 & 994.9 & 27.37 \\
\hline Giza-15 & 259.0 & 78.00 & 20.32 & 9.233 & 36.08 & 1315.9 & 37.25 \\
\hline Sel.1007 & 108.3 & 97.00 & 17.58 & 6.650 & 27.92 & 794.0 & 32.72 \\
\hline CS-3541 & 192.7 & 74.00 & 17.95 & 6.933 & 32.15 & 850.5 & 33.30 \\
\hline Dorado & 109.4 & 90.33 & 20.02 & 7.000 & 29.58 & 1029.3 & 36.42 \\
\hline El-Kharga & 191.0 & 70.67 & 14.17 & 8.983 & 33.18 & 646.9 & 28.97 \\
\hline El-Fayom-1 & 193.5 & 79.00 & 15.98 & 7.633 & 30.37 & 1000.1 & 22.52 \\
\hline El-Fayom-2 & 213.9 & 93.17 & 19.57 & 9.283 & 32.70 & 780.0 & 33.22 \\
\hline Local-162 & 113.3 & 77.67 & 21.12 & 7.750 & 18.52 & 1169.4 & 17.07 \\
\hline Local-119 & 230.3 & 72.83 & 15.72 & 7.383 & 17.77 & 736.0 & 17.95 \\
\hline Line-c & 252.8 & 70.17 & 18.95 & 9.400 & 24.18 & 878.5 & 26.05 \\
\hline Paris-1 & 220.9 & 81.33 & 16.50 & 9.117 & 28.73 & 968.0 & 33.20 \\
\hline L.S.D 0.05 & 8.30 & 2.45 & 1.17 & 0.415 & 1.42 & 91.30 & 2.31 \\
\hline
\end{tabular}

Table 3: Phenotypic correlations for yield and yield components in 15 sorghum genotypes.

\begin{tabular}{|c|c|c|c|c|c|c|}
\hline Traits & $\begin{array}{c}\text { Plant } \\
\text { height }\end{array}$ & $\begin{array}{c}\text { Days to } \\
\mathbf{5 0 \%} \\
\text { flowering }\end{array}$ & $\begin{array}{c}\text { Panicle } \\
\text { length }\end{array}$ & $\begin{array}{c}\text { Panicle } \\
\text { width }\end{array}$ & $\begin{array}{c}\text { 1000-kernel } \\
\text { weight }\end{array}$ & $\begin{array}{c}\text { No. of } \\
\text { seeds/ } \\
\text { Panicle }\end{array}$ \\
\hline Plant height & & & & & & \\
\hline Days to 50\% flowering & -0.447 & & & & & \\
\hline Panicle length & -0.218 & 0.400 & & & & \\
\hline Panicle width & $0.563 *$ & -0.385 & -0.161 & & & \\
\hline 1000-kernel weight & 0.225 & 0.166 & -0.121 & 0.303 & & \\
\hline No. of seeds/ Panicle & -0.067 & -0.098 & 0.326 & 0.225 & 0.130 & \\
\hline Grain weight & -0.067 & 0.354 & 0.108 & 0.179 & $0.749^{* *}$ & 0.272 \\
\hline
\end{tabular}

$*, * *$ significant at $5 \%$ and $1 \%$ level of probabilities, respectively.

The path analysis (Table 4) showed that 1000-kernel weight trait had high positive direct effect on grain weight $(0.7102)$. The panicle length trait had low but positive direct effect on grain weight. Its positive indirect effect was through panicle length (0.0409), days to $50 \%$ 
flowering (0.0770) and number of seeds/panicle (0.0470), whereas its indirect effect was negative through panicle width (-0.0192) and 1000kernel weight $(-0.0856)$. Its positive indirect effects were through days to $50 \%$ flowering $(0.0320)$, panicle width $(0.0361)$ and number of seeds/panicle (0.0187) traits, whereas its indirect effects were negative through plant height $(-0.0421)$ and panicle length $(-0.0058)$ traits. Simi- lar results were obtained by Mahajan et al., (2011) and Aml et al. (2012), they found that panicle length and number of grains /panicle has positive direct effect on grain weight/ panicle. Singh and Baghel (1977), ElMenshawi, (2006) and Aml et al. (2012) found that both number of grains per panicle and 1000-kernel weight were major components of grain weight and also has positive direct effects on grain weight.

Table 4: Direct (diagonal) and indirect effect of different traits on grain weight.

\begin{tabular}{|c|c|c|c|c|c|c|}
\hline Traits & $\begin{array}{c}\text { Plant } \\
\text { height }\end{array}$ & $\begin{array}{c}\text { Days to } \\
\text { 50\% } \\
\text { flowering }\end{array}$ & $\begin{array}{c}\text { Panicle } \\
\text { length }\end{array}$ & $\begin{array}{l}\text { Panicle } \\
\text { width }\end{array}$ & $\begin{array}{l}\text { 1000- } \\
\text { kernel } \\
\text { weight }\end{array}$ & $\begin{array}{c}\text { No. of } \\
\text { seeds/ } \\
\text { Panicle }\end{array}$ \\
\hline Plant height & -0.1876 & -0.0861 & -0.0104 & 0.0670 & 0.1595 & -0.0097 \\
\hline Days to 50\% flowering & 0.0839 & 0.1927 & 0.0191 & -0.0458 & 0.1179 & -0.0141 \\
\hline Panicle length & 0.0409 & 0.0770 & 0.0478 & -0.0192 & -0.0856 & 0.0470 \\
\hline Panicle width & -0.1056 & -0.0742 & -0.0077 & 0.1189 & 0.2155 & 0.0324 \\
\hline 1000-kernel weight & -0.0421 & 0.0320 & -0.0058 & 0.0361 & 0.7102 & 0.0187 \\
\hline No. of seeds/ Panicle & 0.0126 & -0.0189 & 0.0156 & 0.0267 & 0.0921 & 0.1443 \\
\hline
\end{tabular}

\section{Level of polymorphism:}

Fifteen sorghum genotypes in this study were differentiated using 26 RAPD primers, out of them, 12 primers were generated different degrees of genetic polymorphism (Table 5, Figure 1). A band was considered as polymorphic if the band differentiates at least any 2 of the 15 genotypes. Zhan et al. (2012) showed that 22 out of 100 primers were shown to have distinct amplification bands with polymorphisms. In this study, the number of amplification products per primer varied from 4 to 12 , with a mean of 4.67 per primer. Zhan et al. (2012) obtained 3.82 an average number of polymorphic bands per primer. These primers were produced fragments varying from 97 to $1228 \mathrm{bp}$ in size (Table 5). The 12 primers generated a total of 76 RAPD bands across the 15 genotypes, of these bands, only $56(73 \%)$ were polymorphic. This level of variation is much higher than 55\%, 52\% and $58.33 \%$ that observed in Sorghum genotypes by Tao et al. (1993); Nkongolo and Nsapato (2003) and Zhan et al., (2012), respectively. Contrarily, the level of polymorphism is smaller than $85 \%$ which observed between 33 sorghum genotypes by Medraoui et al. (2007). Generally, in this study RAPD markers were more polymorphic than agronomical characterization, but we see that the RAPD markers combined with agronomical characterization provided the most powerful assay for discriminating genetic diversity among sorghum accessions. 
Table 5: Primers used in RAPD analysis, total number of fragments detected by each primer and polymorphism among 15 sorghum genotypes.

\begin{tabular}{|c|c|c|c|c|c|c|}
\hline \multirow{2}{*}{$\begin{array}{l}\text { Primer } \\
\text { Name }\end{array}$} & \multirow{2}{*}{$\begin{array}{c}\text { Primer Sequence } \\
\left(5^{\prime}------3^{\prime}\right)\end{array}$} & \multicolumn{2}{|c|}{ Amplified bands } & \multirow{2}{*}{$\begin{array}{l}\text { Polymorphic } \\
\text { bands (\%) }\end{array}$} & \multicolumn{2}{|c|}{$\begin{array}{l}\text { Fragments } \\
\text { size base pair } \\
\text { (bp) }\end{array}$} \\
\hline & & $\begin{array}{c}\text { Fragments } \\
\text { number }\end{array}$ & $\begin{array}{c}\text { Polymorphic } \\
\text { bands }\end{array}$ & & Larger & Smaller \\
\hline OPC-05 & CACACTCCAG & 8 & 7 & 87.50 & 380 & 160 \\
\hline OPG-09 & CTGACGTCAC & 6 & 5 & 83.33 & 392 & 180 \\
\hline OPAD-06 & AAGTGCACGG & 4 & 3 & 75.00 & 390 & 170 \\
\hline OPA-13 & CAGCACCCAC & 4 & 3 & 75.00 & 160 & 500 \\
\hline OPH-01 & GGTCGGAGAA & 4 & 4 & 100.00 & 350 & 250 \\
\hline OPAM-01 & TCACGTACGG & 4 & 2 & 50.00 & 500 & 340 \\
\hline OPA-17 & GACCGCTTGT & 12 & 9 & 75.00 & 1150 & 97 \\
\hline OPF-20 & AACGGTGACC & 4 & 3 & 75.00 & 360 & 240 \\
\hline OPW-13 & GTTGTTTGCC & 5 & 2 & 40.00 & 330 & 190 \\
\hline OPP-05 & CCCCGGTAAC & 11 & 6 & 54.55 & 1088 & 230 \\
\hline OPAT-08 & TCCTCGTGGG & 4 & 3 & 75.00 & 555 & 245 \\
\hline OPAR-05 & CATACCTGCC & 10 & 9 & 90.00 & 1228 & 160 \\
\hline Mean & & 6.33 & 4.67 & $73.36 \%$ & & \\
\hline
\end{tabular}

Similarity percents analysis:

The genetic similarity percents among the 15 sorghum genotypes were calculated according to the analytical results of electrophoretic band patterns (Table 6) and means of all studied characters (Table 7), and were used UPGMA for cluster analysis. The 15 sorghum genotypes showed large differences in genetic similarity percents based on RAPD markers, which ranged from 48.8 to 91.4\%. Among these genotypes, Giza-54 and Giza-114 exhibited the highest similarity (91.4\%), while CS3541 and Giza-54 showed the lowest similarity $(48.8 \%)$. On the other hand, the similarities based on the means of agronomic traits were less than the similarities which observed by RAPD markers method. These similarity percents were 72.3 to 98.5\% between El-Kharga and Giza15, and between Giza-54 and Paris-1, respectively. Based on some agronomical traits, Zhan et al., (2012) obtained genetic similarity coefficients which ranged from $69.4 \%$ to $89.6 \%$ among 13 sweet sorghum varieties. These results indicated that the phenotypic characterization provide less resolving power than RAPD markers for characterize the diversity between the genotypes. Agrama and Tuinstra, (2003) showed that molecular assays were much more powerful at discriminating genetic diversity than estimates based on geographical and race classification, which revealed high levels of genetic similarity (0.951) among sorghum accessions. 
Table 6: Similarity values percents obtained from 67 RAPD fragments for 15 sorghum genotypes.

\begin{tabular}{|l|c|c|c|c|c|c|c|c|c|c|c|c|c|c|}
\hline \multicolumn{1}{|c|}{ Genotypes } & $\mathbf{( 1 )}$ & $\mathbf{( 2 )}$ & $\mathbf{( 3 )}$ & $\mathbf{( 4 )}$ & $\mathbf{( 5 )}$ & $\mathbf{( 6 )}$ & $\mathbf{( 7 )}$ & $\mathbf{( 8 )}$ & $\mathbf{( 9 )}$ & $\mathbf{( 1 0 )}$ & $\mathbf{( 1 1 )}$ & $\mathbf{( 1 2 )}$ & $\mathbf{( 1 3 )}$ & $\mathbf{( 1 4 )}$ \\
\hline Giza-54(1) & 100.0 & & & & & & & & & & & & & \\
\hline Giza-114(2) & 91.4 & 100.0 & & & & & & & & & & & & \\
\hline $10-1285(3)$ & 88.2 & 85.7 & 100.0 & & & & & & & & & & & \\
\hline Giza-113(4) & 73.7 & 82.1 & 78.9 & 100.0 & & & & & & & & & & \\
\hline Giza-15(5) & 70.0 & 78.0 & 75.0 & 72.7 & 100.0 & & & & & & & & & \\
\hline Sel.1007(6) & 61.5 & 70.0 & 71.8 & 79.1 & 80.0 & 100.0 & & & & & & & & \\
\hline CS-3541(7) & 48.8 & 57.1 & 58.5 & 62.2 & 68.1 & 69.6 & 100.0 & & & & & & & \\
\hline Dorado(8) & 54.5 & 62.2 & 59.1 & 62.5 & 72.0 & 73.5 & 78.4 & 100.0 & & & & & & \\
\hline El-Kharga(9) & 48.9 & 56.5 & 53.3 & 57.1 & 62.7 & 64.0 & 76.9 & 83.6 & 100.0 & & & & & \\
\hline El-Fayom-1(10) & 65.1 & 72.7 & 69.8 & 72.3 & 73.5 & 79.2 & 68.0 & 71.7 & 70.4 & 100.0 & & & & \\
\hline El-Fayom-2(11) & 66.7 & 65.2 & 66.7 & 69.4 & 66.7 & 72.0 & 61.5 & 65.5 & 64.3 & 85.2 & 100.0 & & & \\
\hline Local-162(12) & 56.5 & 63.8 & 60.9 & 72.0 & 69.2 & 74.5 & 67.9 & 64.3 & 63.2 & 87.3 & 87.7 & 100.0 & & \\
\hline Local-119(13) & 68.2 & 66.7 & 72.7 & 62.5 & 72.0 & 69.4 & 62.7 & 66.7 & 65.5 & 83.0 & 87.3 & 85.7 & 100.0 & \\
\hline Line-c(14) & 56.5 & 63.8 & 60.9 & 60.0 & 73.1 & 66.7 & 67.9 & 71.4 & 70.2 & 80.0 & 77.2 & 82.8 & 89.3 & 100.0 \\
\hline Paris-1(15) & 50.0 & 57.1 & 54.2 & 61.5 & 74.1 & 64.2 & 61.8 & 65.5 & 64.4 & 77.2 & 74.6 & 83.3 & 82.8 & 86.7 \\
\hline
\end{tabular}

Table 7: Similarity values percents obtained from agronomical characterization for 15 sorghum genotypes.

\begin{tabular}{|l|c|c|c|c|c|c|c|c|c|c|c|c|c|c|}
\hline \multicolumn{1}{|c|}{ Genotypes } & $\mathbf{( 1 )}$ & $\mathbf{( 2 )}$ & $\mathbf{( 3 )}$ & $\mathbf{( 4 )}$ & $\mathbf{( 5 )}$ & $\mathbf{( 6 )}$ & $\mathbf{( 7 )}$ & $\mathbf{( 8 )}$ & $\mathbf{( 9 )}$ & $\mathbf{( 1 0 )}$ & $\mathbf{( 1 1 )}$ & $\mathbf{( 1 2 )}$ & $\mathbf{( 1 3 )}$ & $\mathbf{( 1 4 )}$ \\
\hline Giza-54(1) & 100.0 & & & & & & & & & & & & & \\
\hline Giza-114(2) & 88.7 & 100.0 & & & & & & & & & & & & \\
\hline $10-1285(3)$ & 88.5 & 77.8 & 100.0 & & & & & & & & & & & \\
\hline Giza-113(4) & 96.2 & 89.7 & 88.1 & 100.0 & & & & & & & & & & \\
\hline Giza-15(5) & 85.8 & 79.4 & 96.4 & 89.1 & 100.0 & & & & & & & & & \\
\hline Sel.1007(6) & 87.5 & 89.8 & 77.8 & 84.7 & 75.0 & 100.0 & & & & & & & & \\
\hline CS-3541(7) & 94.5 & 91.7 & 84.6 & 91.2 & 81.5 & 92.6 & 100.0 & & & & & & & \\
\hline Dorado(8) & 92.2 & 81.4 & 87.9 & 92.3 & 85.1 & 89.6 & 88.7 & 100.0 & & & & & & \\
\hline El-Kharga(9) & 85.4 & 91.1 & 75.4 & 82.0 & 72.3 & 87.0 & 90.0 & 78.3 & 100.0 & & & & & \\
\hline El-Fayom-1(10) & 97.4 & 86.9 & 90.0 & 97.1 & 86.8 & 86.7 & 93.3 & 94.6 & 83.9 & 100.0 & & & & \\
\hline El-Fayom-2(11) & 91.3 & 95.3 & 80.8 & 89.0 & 79.4 & 94.1 & 95.2 & 85.4 & 91.3 & 89.2 & 100.0 & & & \\
\hline Local-162(12) & 87.6 & 77.1 & 92.5 & 87.6 & 89.5 & 82.9 & 83.4 & 93.1 & 73.5 & 90.1 & 79.3 & 100.0 & & \\
\hline Local-119(13) & 89.0 & 97.2 & 77.8 & 87.2 & 77.0 & 89.4 & 91.9 & 80.7 & 92.4 & 86.7 & 94.9 & 77.7 & 100.0 & \\
\hline Line-c(14) & 94.8 & 93.4 & 83.7 & 94.5 & 84.3 & 88.6 & 95.6 & 87.2 & 86.3 & 92.2 & 92.8 & 83.1 & 92.1 & 100.0 \\
\hline Paris-1(15) & 98.5 & 89.0 & 88.5 & 97.2 & 87.0 & 87.4 & 93.8 & 92.9 & 84.2 & 97.2 & 91.6 & 87.6 & 88.7 & 94.4 \\
\hline
\end{tabular}

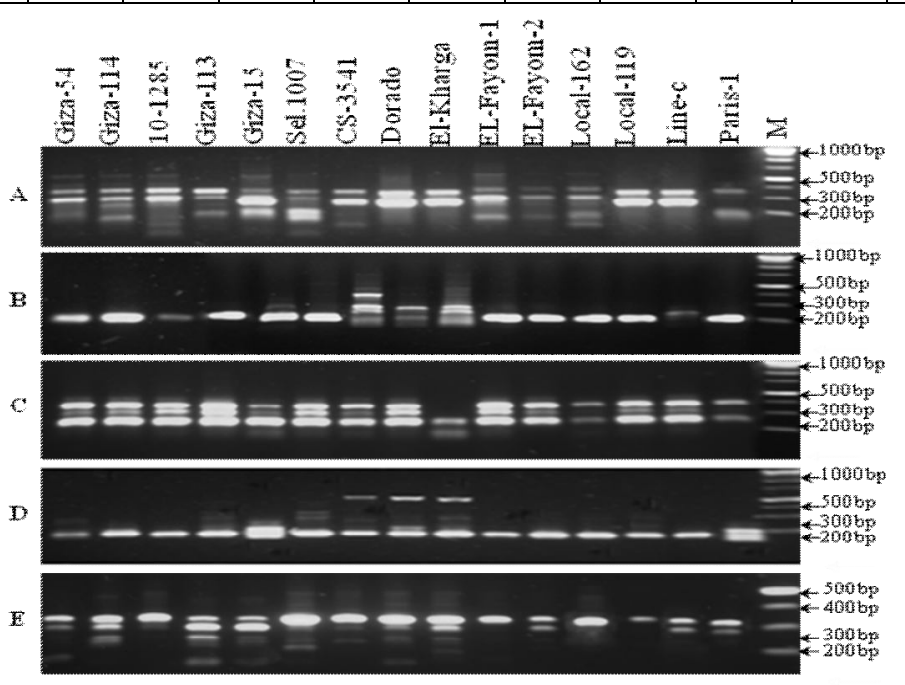

Figure 1: RAPD profiles obtained by RAPD primers A) OPC-05, B) OPG-09, C) OPAD-06, D) OPA-13 and E) OPH-01, $\mathrm{M}=100$ bp ladder. 
Genetic relationship among genotypes:

Based on RAPD analysis, the dendrogram showed that the 15 sorghum genotypes separated into three distinct groups (Figure 2). The first group contains El-Kharga, Dorado and CS-3541 genotypes, but the second group sub-divided into two subclusters. The first sub cluster contains Paris-1, Line-c and Local-119 genotypes; the second sub-cluster contains Local-162 and El-Fayom-2 which clustered at 86.2 level of similarity percent with El-Fayom-1. Also, The third group sub-divided into 2 subgroups, whereas Sel.1007, Giza-15 formed the first sub-group, that clustered at 78.2 level of similarity percent with genotypes Giza-113, 101285, Giza-54 and Giza-114 which formed the second sub-group in dendrogram (Figure 2). Some consistency in classification was observed among clusters, whereas, the genotypes named Giza-15, Giza-54, Giza113 and Giza-114, which originate from the same region in Egypt, were grouped together. Agrama and Tuinstra (2003) showed that sorghum genotypes SC35 and SC1158, which originate from the same region in Ethiopia, were grouped together.

Based on agronomical characterizations, the dendrogram showed that the 15 sorghum genotypes formed two big groups (Figure 3) that clustered at $84.4 \%$ level of similarity percent. Giza-54 and Paris-1 clustered at high level of similarity percent $(98.5 \%)$.

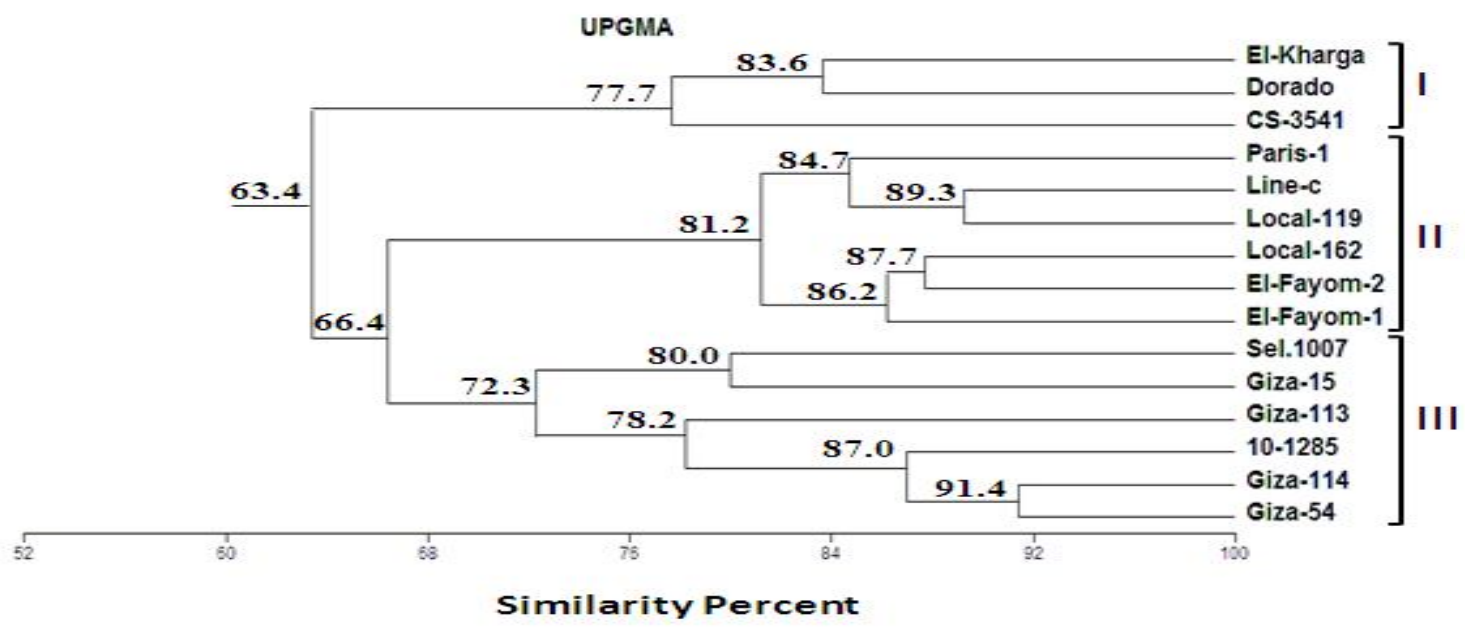

Figure 2: Dendrogram generated by UPGMA cluster analysis using similarities percents that obtained from 67 RAPD fragments.

Correlation between the two distance matrices generated by agronomical traits and RAPD marker was calculated (Figure 4), it is not significant ( $\mathrm{r}$ $=0.07961, \mathrm{p}=0.7594)$, as shown in Figure 4. The observed relationships using molecular markers may provide information on the history and biology of cultivars but it does not necessarily reflect what may be observed with respect to agronomic traits (Metais et al. 2000). Genetic markers like RAPDs may accurately assay the degree of genetic change between two genomes, but they may not necessarily reflect the divergence in terms of changes in traits of agronomic importance. 


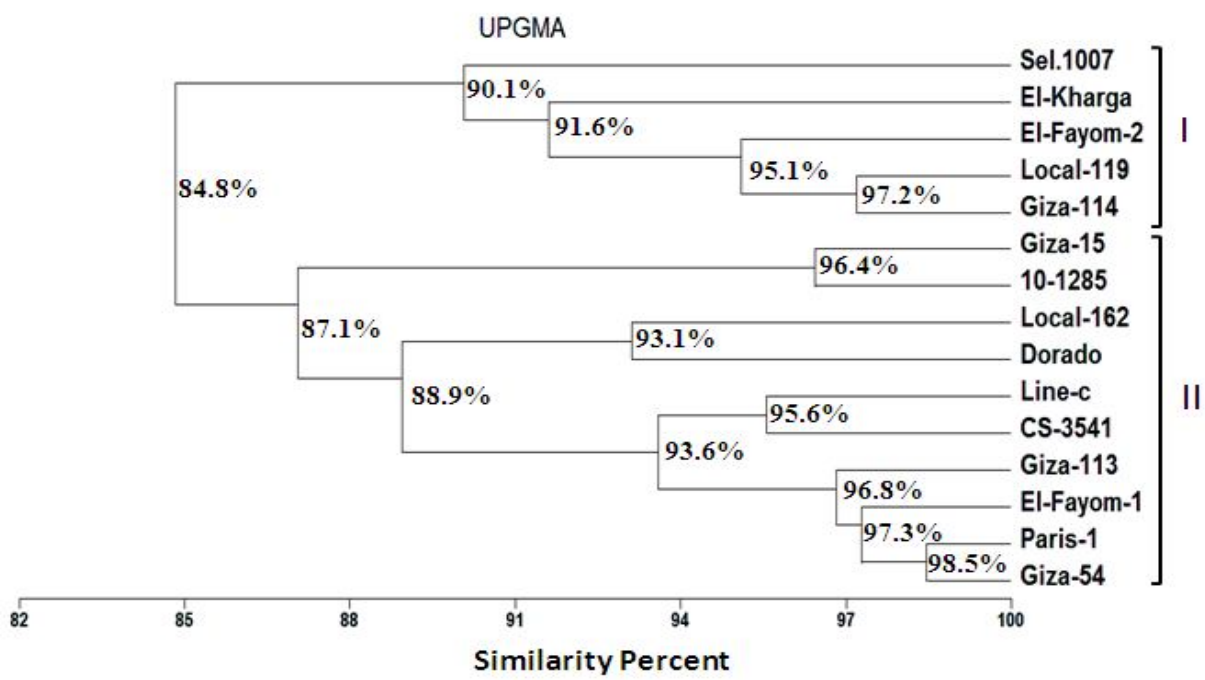

Figure 3: Dendrogram generated by UPGMA cluster analysis using similarities percents that obtained from all studied traits.

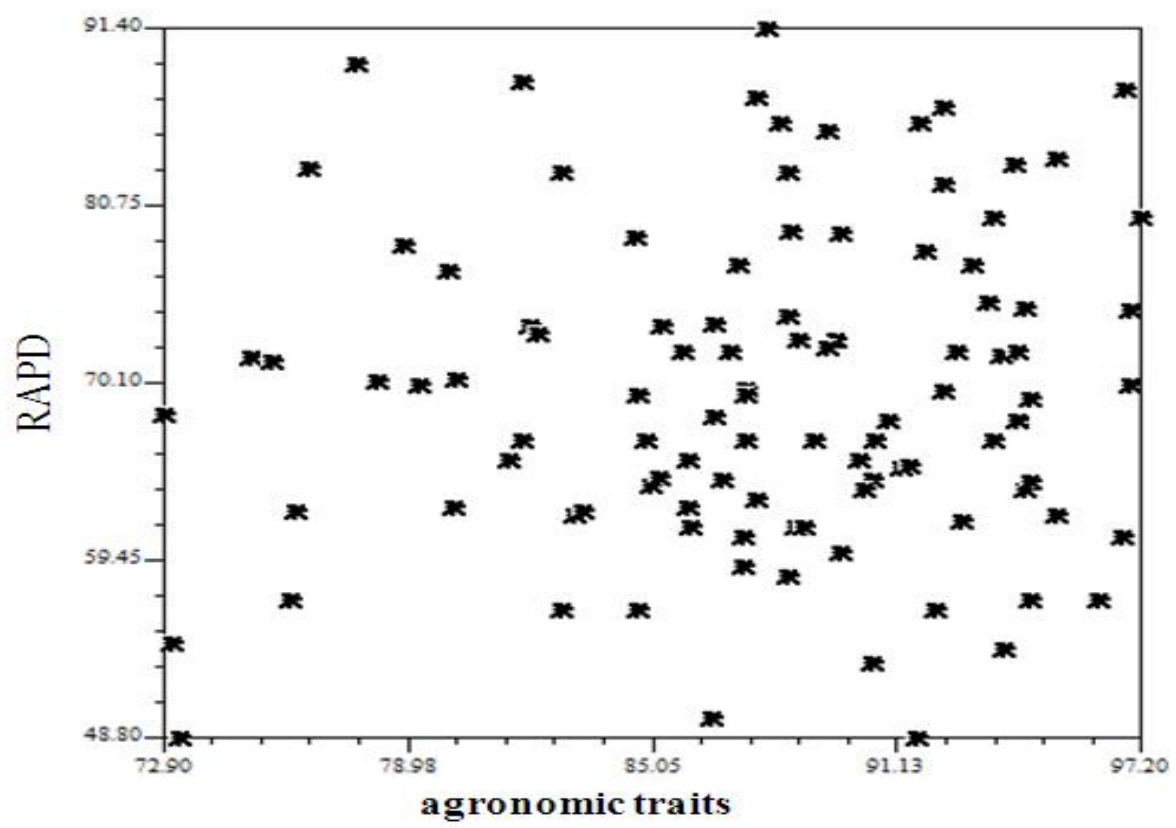

Figure 4: Correlation between similarities percents obtained from RAPD markers and agronomic traits for 15 sorghum genotypes.

\section{Conclusion:}

Our study showed the presence of broad genetic base of the investigated sorghum germplasm. The traits like number of seeds / panicle and 1000-kernel weight had greater importance. Hence, due consideration should be given to these characters, while planning a breeding strategy for increased grain yield/panicle. Finally, the agronomic traits and RAPDs markers are useful for classification of germplasm in sorghum, but a combination of different markers is preferred in studying genetic relationships among the lines of same species. It can be concluded that RAPD markers can be used for sorghum ge- 
netic diversity studies and molecular characterization.

\section{References:}

Abdelsabour GAK, Obiadalla HA, AbdelRehim KA. 2010. Genetic and chemical analyses of six cowpea and two Phaseolus bean species differing in resistance to weevil pest. J. Crop Sci. Biotech. 13: 53-60.

Ambekar SS, Gaikwad DS, Khapre PR, Borikar ST. 2000. Genetic variability and character association and path coefficient studies in selected germplasm lines of Rabi sorghum, paper presented in 8th Vasantrao Naik memorial national agricultural seminar on " Sorghum under different agro-ecological systems and its industrial utilized ". March 1-2, at College of Agriculture, Nagpur.

Aml T El, Hessein EM, Ali EA. 2012. Path Coefficient and correlation Assessment of Yield and Yield Associated Traits Sorghum (Sorghum bicolor L.) Genotypes. American-Eurasian J. Agric \& Environ. Sci. 12: 815-819.

Agrama HA, Tuinstra MR. 2003. Phylogenetic diversity and relationships among sorghum accessions using SSRs and RAPDs. African J. of Biotech. 2: 334-340.

Appa-Rao S, Prasada-Rao KE, Mendesha MH, Gopal-Reddy V. 1996. Morphological diversity in sorghum germplasm from India, Gen. Res. Crop Evol. 43: 559-567.

Ayana A, Bekele E, Bryngelsson T. 2000. Genetic variation in wild sorghum (Sorghum bicolor ssp. Verticilliflorum L. Moench) germplasm from Ethiopia assessed by random amplified polymorphic DNA (RAPD). Hereditas. 132: 249-254.

Burton GW. 1952. Quantitative inheritance in grasses. Proceeding of the 6th International Grassland Congress 1: 227-283.

Cheng KT, Chang HC, Su CH, Hsu FL. 1997. Identification of dried rhizomes of Coptis species using random amplified polymorphic DNA. Bot. Bull. Acad. Sin. 38: 241-244.

Dewey DR, Lu KH. 1959. A correlation and path coefficient analysis of components of crested wheatgrass seed production. Agron. J. 51 :515-518.

Djè Y, Ater M, Lefèbvre C, Vekemans X. 1998. Patterns of morphological and allozyme variation in sorghum genotypes of Northwestern Morocco. Gen. Res. Crop Evol. 45: 541-548.

Dongre A, Parkhi V. 2005. Identification of cotton hybrids through the combination of PCR based RAPD, ISSR and micro satellite markers. J. Plant Biochem. Biotechnol. 14: 53:55.

El-Menshawi MM. 2006. Environmental effects on correlation and path coefficient estimates for three groups of agronomic traits affecting grain yield of sorghum, Egypt .J. Plant Breed. 10: 31-45.

Hoffman D, Hang A, Larson S, Jones B. 2003. Conversion of an RAPD marker to an STS marker for barley variety identification. Plant Mol. Biol. Rep. 21: 81-91.

House LR. 1985. A guide to Sorghum Breeding. $2^{\text {nd }}$ Ed. International Crops Research Institute for the 
Semi-Aride Tropics,Patancheru, India. pp.206.

Ikanovic J, Djordje J, Radojka M, Vera P, Dejan, Marija S, veto RS. 2011. Path analysis of the productive traits in sorghum species. Genetika. 43: 253-262.

Jeya SPP, Biji KR, Gomez SM, Murthy KG, Babu RC. 2006. Genetic diversity analysis of sorghum (Sorghum bicolor L. Moench) accessions using RAPD markers. Indian J. Crop Sci. 1-2: 109112.

Jordan DR, Tao YZ, Godwin ID, Henzel RG, Cooper M, McIntyre CL. 1999. Loss of genetic diversity associated with selection for resistance to sorghum midge in Australia sorghum. Euphytica. 102: 1-7.

Khaled AGA, Hamam KA, Motawea MH, EL-Sherbeny GAR. 2013. Genetic analysis and RAPD markers for tissue culture response and some agronomical traits in Egyptian bread wheat. J. genet. Engineering. Biotech. 11: 79-86.

Mahajan RC, Wadikar PB, Pole SP, Dhuppe MV. 2011. Variability, correlation and path analysis studies in sorghum. Res. J. of Agri. Sci. 2: 101-103.

Mahdy EE, Ali MA, Mahmoud AM. 2011. The effect of Environment on combining ability and heterosis in grain sorghum (Sorghum bicolor L., Moench). Asian J. of Crops Sci. 3: $1-15$.

Mantel NA. 1967. The detection of disease clustering and generalized regression approach. Cancer Res. 27: 209-220.

Mallinath V, Birada BD, Chittapur BM, Salimath PM, Patil S.S.
2004. Variability and correlation studies in pop sorghum, Karnataka J. Agric. Sci. 17: 463-467.

Melchinger AB. 1993. Use of RFLP markers for analysis of genetic relationships among breeding materials and prediction of hybrid performance. In International crop science congress I. CSSA, Madison, WI (Ed). D.R. Buxton. pp.621-628.

Medraoui L, Mohammed A, Benlhabib O, Msikine D, FilaliMaltouf A. 2007. Evaluation of genetic variability of sorghum (Sorghum bicolor L. Moench) in northwestern Morocco by ISSR and RAPD markers. C. R. Biologies. 330: 789-797.

Metais I, Aubry C, Hamon B, Jalouzot R. 2000. Description and analysis of genetic diversity between commercial bean lines (Phaseolus vulgaris L.). Theor. Appl. Genet. 101: 1207-1214.

Mostafa MSA, Attar FL, El Kady AM, Ewies EO. 1992. Heterosis and correlation studies in some grain sorghum hybrids (Sorghum bicolor L.) Moench), Egypt J. appli. Sci. 7: 883-890.

Narasimharao DV, Rachie KO. 1964. Correlation and heritability of morphological characters in grain sorghum. Madras agric. J. $51: 156-161$.

Nkongolo KK, Nsapato L. 2003. Genetic diversity in Sorghum bicolor (L.) Moench accessions from different ecogeographical regions in Malawi assessed with RAPDs. Genetic Resources and Crop Evolution. 50: 149-156.

Poresbski SL, Bailey G, Baum RB. 1997. Modification of CTAB DNA extraction protocol for 
plants containing high polysaccharide and polyphenol components, Plant Mol. Biol. Rep. 12 :8-15.

Rohlf FJ. 2000. NTSYS-pc: Numerical taxonomy and multivariate analysis system. Version 2.1 Exeter Software,Setauket, USA.

Singh RR, Baghel SS. 1977. Yield components and their implication to selection in sorghum. Indian J. Genet. Pl. Br. 37: 125162.

Snedecor GW, Cochran WG. 1989. Statistical Methods, 8th Edition. The lowa State University.

Smith JSC, Smith OS. 1992. Fingerprinting crop varieties, Adv. Agron. $47: 85-140$.

Steel RGD, Torrie JH. 1980. Principles and Procedures of Statistics. McGraw Hill Book.

Tao Y, Manners JM, Ludlow M, Henzel RJ. 1993. DNA polymorphisms in grain sorghum (Sorghum bicolor (L.) Moench). Theor. Appl. Genet. 86: 679688. Tanttawi D, Abdelsabour GAK, Husni MH. 2007. Genetic studies for some agronomic characters in faba bean (Vicia faba
L.), Assiut J. of Agric. Sci. 38 :117-137.

Turner ME, Stevens CD. 1959. The Regression Analysis of Casual path. Biometrics. 15: 236-250.

Wankhede MG, Shekhar VB, Khorgade PW. 1985. Variability, correlation and path analysis studies in sorghum (sorghum bicolor L.). PKV Research J. 9: $1-5$.

Williams JGJ, Kubelik AR, Livak KJ, Rafalski JA, Tingey SV. 1990. DNA polymorphisms amplified by arbitrary primers are useful as genetic markers, Nucl. Acids Res. 18: 6531-6535.

Wright S. 1960. Path coefficient and Path Regression: Alternative or Complementary Concepts. Biometrics. 16: 189-202.

Zhan Q, Zhou L, Bi N, Wu H, Li J, Lu J, Lu J, Lin P. 2012. A comprehensive analysis of genetic diversity and relationships of 13 sweet sorghum varieties as energy sources. J. of Sustainable Bioenergy Systems. 2: 86-91.

Zidenga T. 2004. DNA-based methods in sorghum diversity studies and improvement.I SB News Report March issue. 
الارتباط وتحليل معامل المرور والواسمات الجزيئيه العثوائيه لعدد من التركيب الوراثيه فى

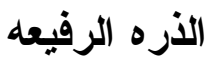

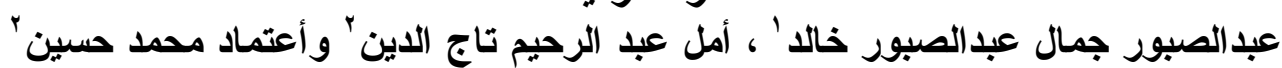

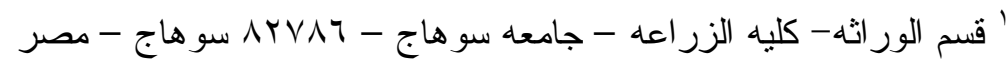

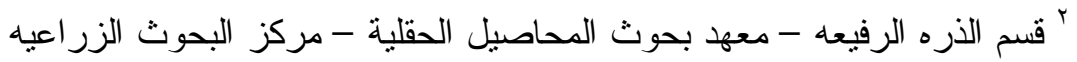

الملخص:

التتوع الور اثى و احد من أهم العو امل الضروريه لتحسين العديد من المحاصــيل و منهـــا

الذره الرفيعه. فى هذه الدر اسه تم زر اعة خمسة عشرة طر از ور اثى من الــذره الرفبعــه فـى المو اسم r I • r و r ـ ـ للمقارنه بينها فى الصفات المحصوليه و الاختلافات الجزيئيه. لقد أظهر التحليل المشترك لصفات المحصول ومكوناته وجود إختلافات معنويه بين هذه التز اكيب الور اثيه

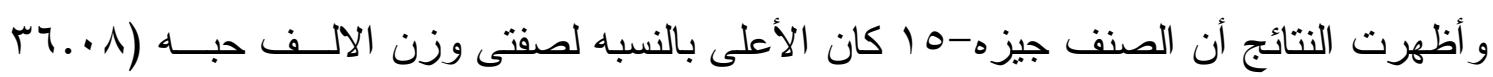
جر ام) و عدد الحبوب فى الكوز (0.9 اب1). كما أتضح أنه يوجد إرنباط موجب عالى المعنويه

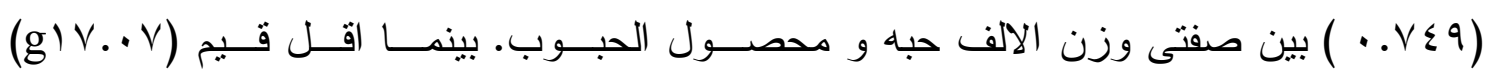

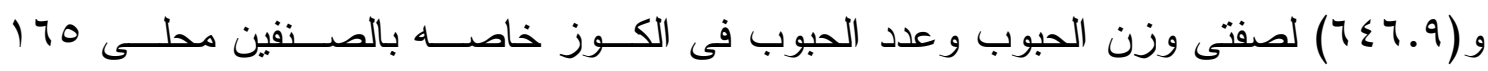
و الخارجه على التو الى. كما أوضحت النتائج المتحصل عليها بدر اسة معامل المــرور لمكونــات المحصول أن وزن الألف حبة لها تأثير عالى موجب ومباشر على صفة المحصول (Y • (V..)

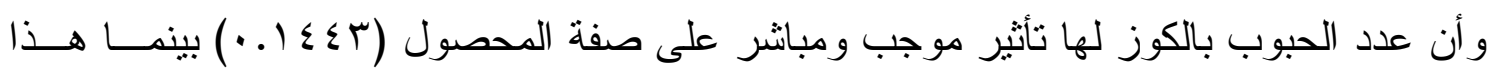
التأثير كان سلبى بالنسبة لطول النبات (_AV7 ( . • ). من ناحيه أخرى تم تقييم التتوع الوراثى فى هذه التز اكيب الور اثيه بإستخدام الو اسمات الجزيئيه العشو ائيه. حيث، تم الحصــول علــى V7

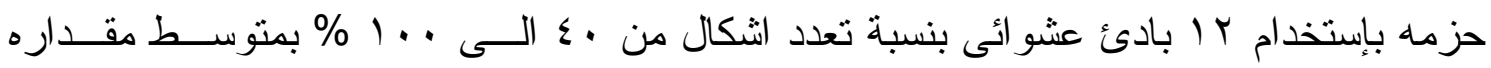
جب. بV\%. كما أظهر تحليل الثجره الور اثيه فى تجربة البادئات العشو ائيه ان الخمســة عشــر تركيب ور اثى تثكل ثثلاثة مجاميع رئيسيه. المجموعه الأولى تحتوى على ثناثة تر اكيب ور اثيـــ و المجمو عه الثانيه انقسمت إلى تحت مجمو عتين حيث تحتوى كل و احده على ثثلاثــة تر اكيــب ور اثيه، بينما المجمو عه الثالثه تحتوى على 7 تز اكيب ور اثيه. فى هذه الدر اسه اتضـح أن نسـبة التشابه بناءا على الصفات المحصوليه اظهرت ارنباط غير معنوى مع تحليل الو اسمات الجزيئيه العشو ائيه. 